\title{
GOVERNANÇA CORPORATIVA: UM NOVO NOME PARA ANTIGAS PRÁTICAS?*
}

\author{
ÁLVARO RICARDINO \\ Professor Doutor do Curso de Mestrado do Centro Universitário Santo André - SP \\ E-mail: ricardino@fsa.br \\ SOFIE TORTELBOOM AVERSARI MARTINS \\ Pesquisadora da FIPECAFI - FEA/USP - SP \\ E-mail: appel@ig.com.br
}

\section{RESUMO}

Em 1754, para tentar reverter a grave crise econômica que se abatia sobre o Estado do Grão-Pará e Maranhão, situado no noroeste do Brasil, o então Governador Francisco Xavier de Mendonça Furtado solicita ao seu irmão, o Marquês de Pombal, Primeiro Ministro de Portugal, que faça esforços junto ao rei para a aprovação de uma companhia de comércio destinada a transportar escravos negros para serem comercializados naquele Estado, como forma de substituir a mão-de-obra indígena, pouco acostumada ao trabalho. Objetivando adiantar o processo e contando apenas com sua memória e experiência, o Governador redigiu e encaminhou ao irmão a minuta dos estatutos daquele empreendimento. Seus vinte e sete parágrafos podem ser considerados avançados para a época e possuem diversos conceitos que hoje são práticas recomendáveis de Governança Corporativa. Considerando-se que mais de duzentos anos separam a iniciativa de Mendonça Furtado dos estudos sobre Governança Corporativa, vale perguntar: Governança Corporativa é um novo nome para antigas práticas?

Palavras-chave: Governança Corporativa, História da Contabilidade, Companhia Geral de Comércio do Grão-Pará e Maranhão.

\section{ABSTRACT}

In 1754 , in an attempt to revert the serious economic crisis that hit the State of Grão Pará and Maranhão, located in the Northeast of Brazil, the Governor at that time, Francisco Xavier de Mendonça Furtado, asked his brother, the Marquis of Pombal, Prime Minister of Portugal, to make his best effort at the royal palace to approve a trading company aimed at transporting black slaves to be traded in that state, in order to substitute for indigenous workforce, which was little accustomed to this work.

With a view to fastening the process, on the mere basis of his memory and experience, the Governor wrote and sent his brother the minutes of that company's bylaws. His twenty-seven paragraphs can be considered ahead of their time and contain various concepts recommended as Corporate Governance practices nowadays.

Considering that there are more than two hundred years between Mendonça Furtado's initiative and studies on Corporate Governance, it should be asked: Is Corporate Governance a new name for ancient practices?

Keywords: Corporate Governance, Accounting History, Grão Pará and Maranhão General Trading Company. 


\section{INTRODUÇÃO}

Embora a literatura consagre a segunda metade do século $X X^{1}$ como o início das tentativas de regulamentar e consolidar as práticas de Governança Corporativa, é intuitivo que a preocupação com a "maximização do desempenho da empresa e acesso ao capital"2 sempre foi uma das preocupações dos investidores, entendidos como tal o dono do capital que não participa diretamente da gestão da empresa, mas tão somente de seus resultados.

Um exemplo surpreendente da intenção de constituir um empreendimento sob o signo das boas práticas de Governança Corporativa - ainda que o autor nem de longe pudesse sonhar com o alcance dessas palavras no futuro - pode ser encontrado na minuta dos estatutos de constituição da Companhia Geral de Commércio do Grão-Pará e Maranhão, elaborado sob condições absolutamente intuitivas.

O adjetivo "surpreendente", utilizado para caracterizar o empreendimento, justifica-se no tempo e no espaço:

- Data: 15 de fevereiro de 1754.

- Localização: Brasil, Estado do Grão-Pará e Maranhão.

Para consubstanciar tal afirmativa, é importante efetuar alguns breves esclarecimentos sobre a localização geográfica do empreendimento e as condições socioeconômicas vividas pelos habitantes daquela região até aquele momento.

- Localização geográfica: o Estado do Grão-Pará e Maranhão situava-se na região noroeste do Brasil, compreendendo desde o atual Estado do Ceará até o extremo oeste da região Amazônica, incluindo os atuais Estados do Tocantins e Mato Grosso, cobrindo uma extensão de mais de $9.900 .000 \mathrm{~m}^{2}$.

- Condições socioeconômicas: as primeiras tentativas de colonização da área tiveram início no século XVII. A monarquia portuguesa estava preocupada em estender seus domínios para o norte, objetivando a formação de colônias permanentes para defender o solo dos ataques de holandeses, franceses e ingleses. O problema é que o solo maranhense não produzia canade-açúcar com a mesma fecundidade que as demais regiões brasileiras. Para piorar, a essa dificuldade somavam-se outras, tais como: dispersão geográfica, falta de mão-de-obra, insuficiência de apoio econômico, etc. Assim, durante a segunda metade do século XVII e primeira do século XVIII, o esforço dos colonos daquele Estado estava voltado, basicamente, à sobrevivência. Furtado (1980, p. 91) resume a situação de penúria em que viviam os habitantes de São Luiz, a segunda principal cidade do Estado: "uma pequena colônia, em cujo porto entravam um ou dois navios por ano, e cujos habitantes dependiam do trabalho de algum índio escravo para sobreviver."

\section{METODOLOGIA DE PESQUISA}

O presente artigo pode ser classificado como "história geral" e sua tipologia pertence à categoria dos estudos que fornecem pontos de referência básica para a identificação de circunstâncias passadas que têm influência nos conceitos e práticas contábeis atuais. Nesse contexto, três questões básicas são propostas: a) O que ocorreu? b) Como ocorreu? e c) Por que ocorreu?

Para responder a tais indagações recorreu-se à metodologia desenvolvida por Yin (1994) que solicita explicar como o fato ocorreu e as razões para sua ocorrência.

\section{A GÊNESIS DA COMPANHIA GERAL DO GRÃO-PARÁ E MARANHÃO}

A Companhia Geral do Grão-Pará e Maranhão nasceu por iniciativa de Francisco Xavier de Mendonça Furtado, irmão do Marquês de Pombal, premido pela necessidade de encontrar uma solução que viabilizasse economicamente o Estado do Grão-Pará e Maranhão, do qual era governador no início da segunda metade do século XVIII. O conteúdo de uma

\footnotetext{
1 A respeito das origens da Governança Corporativa vide Carlsson (2001, p. 307), Siffert Filho (1998, p. 2), Jansen e Meckling apud Silveira (2002, p. 13).

2 Texto extraído da definição de Governança Corporativa publicado pelo IBGC - Instituto Brasileiro de Governança Corporativa (<www.IBGC.org.br >), para o qual esta "é um conjunto de práticas e relacionamentos entre acionistas/cotistas, conselho de administração, diretoria, auditoria independente e conselho fiscal, cuja finalidade é otimizar o desempenho da empresa e facilitar o acesso ao capital" (grifo nosso).
} 
série de correspondências oficiais e particulares trocadas entre ambos, a partir de 1751, permite acompanhar as origens e evolução da empresa.

A primeira das cartas data de 21 de novembro de 1751. Em linhas gerais, a correspondência aponta a Companhia de Jesus e as isenções tributárias que aquela ordem religiosa desfrutava como as causas da extrema penúria em que viviam os habitantes locais. O governador informa, ainda, que a região dependia de uma agricultura incipiente e do comércio do conteúdo nativo das florestas. Os moradores de origem européia não trabalhavam e, por conseqüência, nada produziam.

Ambas as opções dependiam da mão-de-obra dos índios da região que, em função da catequese pregada pelos jesuítas da Cia. de Jesus, trabalhavam quase que exclusivamente para eles, em regime de semiescravidão. Como resultado, a maior parte dos itens consumidos localmente ou exportados para Portugal eram comercializados pelos jesuítas. As isenções fiscais que lhes foram concedidas pela coroa portuguesa inviabilizavam qualquer tentativa de competição por parte dos comerciantes locais que não gozavam de tais privilégios. A gravidade da situação foi assim descrita pelo governador:

Como os regulares [jesuítas], assim como não pagam direitos dos efeitos [produtos] da terra também não pagam, com o pretexto das missões, nem o Consulado e Mercearia [repartições do governo português], em Lisboa, nem neste estado à Alfândega, e como não pagam direitos em parte alguma, se demonstra por um verdadeiro cálculo que na balança do comércio vêm a ganhar os padres 80 por 100 contra os seculares [comerciantes locais], e dele compreenderá V. Exa. o progresso que podem fazer os pobres negociantes quando têm contra si o Corpo Poderoso [os jesuítas] com 80 por 100 de ganho certo no comércio contra eles.

(MENDONÇA, 1982, p. 32)

A desvantagem dos comerciantes locais era tal que os habitantes do Estado estavam reduzidos à miséria. "[...] porque apesar de tudo estão os seus Reais
Erários extintos e sem esperança de remédio; os seus vassalos reduzidos à última pobreza e miséria, e tal que não há um só nesta capitania que possa pagar de dívida 30 réis [...]" (MENDONÇA, 1982, p. 33).

As palavras do governador dão a exata dimensão da gravidade daquele momento e demonstram a necessidade de tentar promover iniciativas que ajudassem a superar o problema.

Dois anos e muitas cartas depois, Mendonça Furtado encaminha a seu irmão nova correspondência na qual propõe a criação de uma companhia de comércio. A explanação de seu projeto está contida no texto da $52^{\text {a }}$ carta datada de 24 de janeiro de 1754 :

Entre diversas idéias que me têm ocorrido para poder se reparar em parte o lastimável estrago a que estas duas capitanias (Maranhão e Grão Pará) se reduziram, nenhuma me pareceu melhor do que estabelecer aqui uma Companhia Geral de Comércio, que pudesse introduzir neste Estado tal quantidade de negros que os senhores de engenho e das mais fazendas achassem uma feira pronta, onde os comprassem por preço competente e se pudessem assim redimir da última ruína em que se acham.

(MENDONÇA, 1982, p. 35)

O empreendimento, que no fundo não passava de um tráfico oficial de mão-de-obra escrava, procurava atingir dois objetivos: introduzir uma mão-de-obra mais resistente e qualificada do que a dos indígenas e tirar o monopólio comercial da mão dos missionários.

De início a idéia foi rebatida pelos habitantes locais sob a alegação de falta de recursos para viabilizar o empreendimento, porém, com a adesão dos oficiais militares da região, seguida da adesão dos comerciantes, foi possível reunir a quantia de 32 mil cruzados, montante que causou espanto ao próprio autor do projeto. Entusiasmado com o resultado, o governador estendeu seu plano aos moradores do Maranhão que também acabaram por aderir.

A iniciativa não era original. Antes dela dois outros empreendimentos foram criados para exploração comercial do território brasileiro: Companhia Geral do Comércio do Brasil (1647) e Companhia do Maranhão (1682). Não obstante, esse novo empreendimento 
resultou naquela que foi a primeira sociedade por ações de origem luso-brasileira ${ }^{3}$, concebida em território brasileiro: "para que pudessem entrar até os pequenos cabedais [recursos financeiros], Ihes estabeleci a Companhia por ações de cem mil-réis, ficando livre a cada um o entrar com muitas ou com uma só para facilitar as entradas." (MENDONÇA, 1982, p. 36).

Ainda na mesma carta, Mendonça Furtado solicita que Pombal intermedeie, junto ao rei, a isenção tributária do empreendimento, regalia que parecia ser inédita aos empreendimentos privados: "enquanto ao último de não ficarem sujeitos ao Fisco os cabedais da Companhia, vejo que é novo e que não tem exemplo [...]". Mais adiante a argumentação em prol da solicitação é reforçada "[...] S. Maj. concedendo esta isenção à Companhia, faz um negócio sumamente útil aos interesses da sua real coroa." (MENDONÇA, 1982, p. 37).

Três semanas após, Mendonça Furtado escreve outra carta ao irmão 4 para comunicar que havia reunido o capital inicial de 250 mil cruzados e que havia preparado uma minuta dos estatutos da empresa.

Os estatutos, em sua versão primeira, reúnem alguns predicados dignos de admiração, a começar pela ausência de parâmetros para sua redação:

Como esta Companhia se não podia fundar senão debaixo de certas condições que fossem úteis aos interessados e que elas mesmas Ihes servissem de leis para se governarem, me vi em sumo embaraço para se fazerem, porque não há uma única pessoa nesta terra que entenda destes estabelecimentos [assunto].

[...]

Porque não tenho aqui livro algum que trate desta matéria, nem cópia de algum destes estabelecimentos para poder guiar por eles e acomodá-los ao modo do país, foi-me preciso o fazer as ditas condições à força de discurso, e com alguma leve memória de alguma coisa que vi, e por cuja razão desenganei aos interessados que, sem embargo da satisfação em que estavam, mandassem a
Lisboa consultar aos seus cabedais com a segurança que coubesse no possível. [deixa os interessados à vontade para consultar em Lisboa profissionais que pudessem avaliar adequadamente os citados estatutos]

$$
\text { (MENDONÇA, 1982, p.39) }
$$

Outro fato notável, talvez o maior, consiste na preocupação de criar mecanismos, inclusive contábeis, que "me pareceram poderiam concorrer para a boa administração do negócio [...]" (MENDONÇA, 1982, p. 40).

O fracasso e as condições fraudulentas de liquidação de empreendimentos anteriores àquele, em Portugal, respaldam ao zelo do governador:

A autoridade que os interessados [acionistas] pedem a S. Maj. para os diretores da Companhia, parece-me que concorrerá para muito se obviarem as infinitas fraudes com que esta gente costuma enredar os negócios para nunca se acharem contas, e enquanto se extingue o dinheiro de trapaças com que os advogados costumam inutilizar as coisas dessa natureza, se arruína inteiramente o comércio, padecem os interessados e rara vez ou nunca se consegue a conta-corrente de que V. Exa terá visto um montão de exemplos na nossa corte, principalmente em quantas Companhias se quiseram estabelecer, as quais contas se destruíram com demandas eternas e, sabendo eu de algumas, ainda não me consta que nenhuma delas tivesse fim.

(MENDONÇA, 1982, p. 40)

Após concluir a carta informando ao irmão "[...] o amor que tenho a este novo estabelecimento [empreendimento] e a ânsia de o ver prosperar", Mendonça Furtado anexa a minuta dos estatutos que possui o seguinte título: CONDIÇÕES COM QUE SE DEVEM FUNDAR A NOVA COMPANHIA QUE OS

\footnotetext{
3 A expressão "luso-brasileira", neste contexto, ignora o sentido político e compreende apenas o distanciamento geográfico.

$454^{\mathrm{a}}$ carta, datada de 15 de fevereiro de 1754
} 
MORADORES DA CAPITANIA DO PARÁ INTENTAM ESTABELECER PARA COM ELA FORNECEREM DE NEGROS O ESTADO DO MARANHÃO E MINAS DO MATO GROSSO.

\section{CRITÉRIOS PARA ANÁLISE DA MINUTA DOS ESTATUTOS}

O documento, composto de 27 artigos, indica uma série de iniciativas que, dois séculos e meio depois, são comparáveis a algumas das principais práticas do que hoje denominamos Governança Corporativa. Dado seu aspecto progressista para a época em que foi redigido e para não truncá-lo, optamos por reproduzi-lo na íntegra, muito embora nem todos os artigos contenham ingredientes de Governança Corporativa. Os que não se enquadram nessa categoria mantêm seu interesse por estarem voltados para aspectos tais como: controles internos, regis- tros contábeis e até incorporação do ágio na venda das ações.

Para efeito de análise nos artigos em que as propostas são comparáveis às atuais práticas de Governança Corporativa, foram utilizados como benchmark, os seguintes trabalhos: Euroshareholders Corporate Governance Guidelines 20005, Global Corporate Governance Principles ${ }^{6}$ e Código das MeIhores Práticas de Governança Corporativa, recomendadas pelo IBGC - Instituto Brasileiro de Governança Corporativa ${ }^{7}$.

Além dos comentários contidos na coluna "análise/texto", a identificação do benchmark compatível com a prática adotada encontra-se na coluna "Ref." identificado com as letras "A" para as práticas indicadas pela Euroshareholders, "B" para as indicadas pela Global, e "C" para as indicadas pelo IBGC.

\subsection{ANÁLISE COMPARATIVA}

do Grão Pará e Maranhão

Art. Texto

1 Que esta companhia será estabelecida com mil ações de cem mil réis cada uma, ficando livre a cada pessoa o entrar com uma ou muitas ações..

2 Que depois de contemplar as ditas mil ações, poderá a companhia tornar a receber outras mil ações, sendo o preço destas segundas o de cento e cinqüenta mil réis.

3 Que [...],depois de completar as segundas ações, [...], poderão os diretores receber outras mil ações; sendo porém estas terceiras a $200 \$$ rs cada uma, e tanto as segundas, como estas terceiras se reputarão somente a $100 \$$ rs por ação, como as primeiras, ficando a mais quantia com que entrarem [diferença entre valor de aquisição e valor nominal] incorporadas aos fundos da companhia.

4 Que, por quanto não será possível que a Companhia possa ter uma sólida subsistência se a cada um dos acionistas for permitido tirar, quando quiser, a quantia com que entrar, [...]; não poderá, nenhuma pessoa, [...] tirar o dinheiro com que entrar nela, e só poderá livremente vender, a quem lhe parecer, o direito das ações com que tiver metido na caixa da dita Companhia.

5

Que esta Companhia será dirigida assim no Pará como em Lisboa por quatro Administradores, que serão os Caixas do negócio e a estes competirá inteiramente a administração de todos os interesses da Companhia.
Análise

Texto Ref.

Os estatutos não distinguem as ações quanto à espécie, mas, como se verá mais à frente, no artigo $6^{\circ}$, todas tinham direito a voto.

Verifica-se aqui a figura do ágio na compra das ações de segunda emissão.

Este artigo além da figura do ágio indica sua destinação, um conceito sem dúvida avançado para a época. Não há indicação da forma de contabilização.

Ao definir a forma e comercialização da participação societária, o artigo denota a preocupação com a continuidade do empreendimento. Vale lembrar que a Bolsa de Valores de Lisboa somente foi formalmente constituída em 01 de Outubro de 1901. Até então, a Bolsa de Lisboa apresentava características bem diferentes das atuais, estando voltada à transação de mercadorias e respectivos títulos representativos. (MACHADO, 2004, p. 1)

\footnotetext{
5 Vide: www.ecgi.de/codes/country_documents/pan_european/european_shareholders.pdf

6 Vide: www.calpers-governance.org/principles/international/global/page09.asp

Vide: www.IBGC.org.br
} 


\begin{tabular}{|c|c|c|c|}
\hline \multicolumn{2}{|r|}{$\begin{array}{l}\text { Estatutos da Cia. de Commércio } \\
\text { do Grão Pará e Maranhão }\end{array}$} & \multicolumn{2}{|l|}{ Análise } \\
\hline Art. & Texto & Texto & Ref. \\
\hline 6 & $\begin{array}{l}\text { Para se elegerem os ditos Administradores, serão con- } \\
\text { vocados todos os interessados que quiserem vo- } \\
\text { tar }^{8} \text {, e estes elegerão livres, pessoas da mesma soci- } \\
\text { edade, para que façam a eleição dos quatro adminis- } \\
\text { tradores. }\end{array}$ & $\begin{array}{l}\text { Subentende-se aqui um princípio básico de GC: "a cada } \\
\text { ação um voto". Embora a seqüência de redação dos } \\
\text { artigos } 6^{\circ} \text { a } 8^{\circ} \text { seja confusa, os acionistas elegeriam } 13 \\
\text { sócios, equivalentes a um Conselho de Administração } \\
\text { (vide artigo } 7^{\circ} \text { ), os quais elegeriam os quatro Adminis- } \\
\text { tradores mencionados nos artigos } 5^{\circ} \text { e } 6^{\circ} \text {. }\end{array}$ & A, B \\
\hline 7 & $\begin{array}{l}\text { Logo que as ditas } 13 \text { pessoas forem nomeadas [...] } \\
\text { daqueles interessados que Ihes parecerem mais ca- } \\
\text { pazes, elegerão os dito quatro administradores, tendo } \\
\text { sempre diante dos olhos, que da boa ou má escolha } \\
\text { dos ditos Administradores depende o sólido estabele- } \\
\text { cimento e aumento da dita Companhia, ou sua total } \\
\text { ruína. }\end{array}$ & $\begin{array}{l}\text { A intenção do legislador vai ao encontro das práticas de } \\
\text { GC que indicam que:"O conselho de administração ele- } \\
\text { ge e destitui o executivo principal”. Neste caso, os Dire- } \\
\text { tores, equivalentes a um Conselho de Administração, } \\
\text { elegeriam não apenas um, mas os quatro principais exe- } \\
\text { cutivos, já que todos possuíam iguais poderes. }\end{array}$ & $\begin{array}{l}\text { C } \\
\text { Item } \\
2.28\end{array}$ \\
\hline 8 & $\begin{array}{l}\text { Estes Caixas e Administradores logo que forem eleitos, } \\
\text { mandarão fazer um cofre de quatro chaves, para cada } \\
\text { um ter a sua, no qual se recolherá o cabedal que for } \\
\text { correndo [numerário transacionado] e nunca poderá um } \\
\text { só, por si, receber quantia alguma pertencente ao co- } \\
\text { mum da Companhia, por módica que seja, nem fazer } \\
\text { compra, venda ou pagamento [...] porque, para qualquer } \\
\text { dos sobreditos atos, concorram todos juntos os quatro } \\
\text { ditos Administradores [...] }\end{array}$ & $\begin{array}{l}\text { Verifica-se aqui a intenção da aplicação de controles } \\
\text { internos que invalidassem iniciativas individuais que } \\
\text { pudessem resultar em manipulações ou vantagens } \\
\text { pessoais. }\end{array}$ & \\
\hline 9 & $\begin{array}{l}\text { Para que haja boa expedição [desenvolvimento] nos ne- } \\
\text { gócios pertencentes a dita Companhia, se juntarão os di- } \\
\text { tos Administradores ao menos três dias por semana [...] } \\
\text { naquela casa que for acordada pelos ditos Administrado- } \\
\text { res, na qual se conservarão os livros em boa guarda. }\end{array}$ & $\begin{array}{l}\text { Refere-se aos livros contábeis sem, contudo, } \\
\text { especificá-los. }\end{array}$ & \\
\hline 10 & $\begin{array}{l}\text { Os Administradores, de comum acordo, elegerão o local } \\
\text { mais seguro para depositarem o cofre da Companhia. }\end{array}$ & $\begin{array}{l}\text { Simples aplicação de medidas de segurança e controles } \\
\text { internos. }\end{array}$ & \\
\hline 11 & $\begin{array}{l}\text { Os mesmos Administradores serão obrigados, logo } \\
\text { que chegar qualquer navio da Companhia a este porto, } \\
\text { [...] a dar umas relações públicas aos interessados } \\
\text { [acionistas], dos empregos que se fizeram em Lisboa } \\
\text { [conteúdo adquirido e embarcado em Lisboa]; a nave- } \\
\text { gação que fizeram os navios, e que portos donde fo- } \\
\text { ram; os empregos [aquisições] e despesas que fize- } \\
\text { ram nelas; os efeitos [mercadorias] que trouxeram; e } \\
\text { depois de feitas as vendas, farão outras relações do } \\
\text { que importaram os ditos efeitos [valor obtido com a } \\
\text { venda], a carga que os navios transportaram para o } \\
\text { reino, para que os ditos interessados sejam plena- } \\
\text { mente informados da forma que se maneja o negócio } \\
\text { da boa fé do comércio, e dos lucros que podem espe- } \\
\text { rar deles, cujas relações serão também remetidas para } \\
\text { os Administradores, para que os interessados do rei- } \\
\text { no sejam da mesma forma informados. }\end{array}$ & $\begin{array}{l}\text { Um princípio presente às boas práticas de Governança } \\
\text { Corporativa diz respeito ao disclosure. Nesse particular, } \\
\text { é nítida a intenção do redator da minuta de que todas as } \\
\text { operações - e não apenas o resultado final de um perí- } \\
\text { odo - da entidade sejam conhecidas em detalhes por } \\
\text { todos os acionistas.A intenção era extremamente sau- } \\
\text { dável, principalmente se for levado em conta que o em- } \\
\text { preendimento estava localizado em dois países distan- } \\
\text { tes, as viagens eram longas e esperar pelo fechamento } \\
\text { contábil de um período poderia ser desaconselhável, } \\
\text { principalmente se as atividades não estivessem } \\
\text { correspondendo economicamente às expectativas. }\end{array}$ & A, B \\
\hline 12 & $\begin{array}{l}\text { Os Caixas e Administradores de Lisboa serão obrigados } \\
\text { a fazer semelhantes relações [...] }\end{array}$ & $\begin{array}{l}\text { As informações preparadas no Brasil deveriam ser igual- } \\
\text { mente preparadas em Portugal para conhecimento de } \\
\text { todos os acionistas. }\end{array}$ & \\
\hline 13 & $\begin{array}{l}\text { Os Caixas e Administradores farão as mesmas confe- } \\
\text { rências que os do Pará [...] }\end{array}$ & Idem anterior. & \\
\hline 14 & $\begin{array}{l}\text { No que diz respeito ao cofre de Lisboa, se observará } \\
\text { também o que está disposto a respeito da administração } \\
\text { do Pará [...] }\end{array}$ & $\begin{array}{l}\text { Estende a Portugal os mesmos controles estabelecidos } \\
\text { no Brasil. }\end{array}$ & \\
\hline
\end{tabular}

${ }^{8} \mathrm{O}$ grifo não consta do original. 


\begin{tabular}{|c|l|}
\hline \multicolumn{2}{|c|}{$\begin{array}{c}\text { Estatutos da Cia. de Commércio } \\
\text { do Grão Pará e Maranhão }\end{array}$} \\
\hline Art. & \multicolumn{1}{|c|}{ Texto } \\
\hline 15 & $\begin{array}{l}\text { Porquanto os Administradores hão de ter trabalho com } \\
\text { esta administração, [...] terão de prêmio, nos ganhos da } \\
\text { Companhia 100\$ rs por ano, e o que tomar por sua conta } \\
\text { o escrever e por em arrecadação aos livros da Compa- } \\
\text { nhia [os negócios gerados por eles com resultados re- } \\
\text { vertidos para a empresa], se Ihes darão mais } 60 \$ \text { rs, } \\
\text { pelos mesmos ganhos [...] }\end{array}$ \\
\hline
\end{tabular}

16 [...] e havendo alguma despesa miúda que não mereçam pela sua tenuidade [pequeno valor] estender-se por termo [descrição detalhada] no mesmo livro, serão feitas em róis [relação, resumo] os quais serão examinados pelos Administradores [...]

17 Os livros que houver para se escrever na Companhia serão rubricados pelo Diretor Corregedor desta Comarca [...]

18 Todas as vezes que se provar omissão culpável em qualquer dos Administradores [...] serão convocados os treze Diretores, e estes, na mesma forma que no princípio, poderão por outro administrador no lugar daquele que for compreendido na sobredita culpa [...] e reserva para si, o conservar ou expulsar os sobreditos Administradores conforme entender que é mais conveniente aos interessados da mesma Companhia.

19 Os Administradores serão obrigados depois que daqui [Brasil] sair qualquer navio com sua carga, a por corrente e líquida sua conta [prestar contas atualizadas], e os treze Diretores nomearão dois dos interessados [acionistas] mais peritos para que assistem [verifiquem] e tomem as contas aos quatro Administradores, de cuja resulta [conclusão] darão conta aos mesmos Diretores para que estes não só saibam, mas façam público o como vai a administração do cabedal [recursos] da Companhia.

20 [...] não poderão os acionistas pedir os interesses [lucros] de suas ações, antes do tempo de três anos [...] e passados os ditos três anos se fará a primeira distribuição de lucros, aos ditos interessados [...]

21 Depois de feita a primeira repartição [distribuição], serão os quatro Administradores obrigados a dar conta de dois em dois anos aos dois interessados [peritos que examinarão as contas] que hão de nomear os treze Diretores, e os lucros que houver na Companhia farão repartição [serão divididos], por todos os acionistas, a assim se observará em todo o mais tempo futuro.

22 Os dois interessados, que hão de tomar as contas dos quatro Administradores, serão obrigados, depois de as concluírem, darem parte aos 13 Diretores do estado em que as acharam [opinião sobre as contas da empresa], e farão termo [encerramento] no livro em que as tomaram, que assinarão com os quatro Administradores.

23 Se depois de aprovarem as contas e de terem feito e assinado o termo expressado na condição próxima, constar legitimamente de alguma dívida que os Administradores devam ao cofre, a qual por dolo encobrirem, ficarão todos
Análise

Texto

Ref.

Os estatutos previam, inclusive, os aumentos de remuneração à medida da subscrição de novas emissões de ações. A divulgação das bases de remuneração dos $A, B$, principais executivos da entidade é prática consagrada C de Governança Corporativa.

Estabelece uma forma de controle para pequenas despesas.

Oficializa a abertura dos livros de escrituração sem, contudo, especificá-los.

Reforça as prerrogativas dos Diretores (equivalentes a um Conselho de Administração) de nomear e destituir os diretores da empresa, tal qual descrito no artigo sétimo.

É uma presunção falar sobre auditoria em Portugal, em 1754, no entanto, é óbvia a intenção do governador ao estipular o exame das contas por "dois dos interessados mais peritos ${ }^{9}$ para que assistem e tomem as contas aos quatro administradores", e "façam público o como vai a administração do cabedal da Companhia". Ao utilizar a expressão "façam público" fica novamente patente a intenção do disclosure na condução dos negócios.

Inicia o artigo explicando a impossibilidade de auferir lucros antes de três anos e estabelece esse tempo, como mínimo, para a obtenção e distribuição de resultados.

Estipula a periodicidade da apuração de resultados em A, B dois anos. Conquanto os atuais princípios de Governança Corporativa estipulem esse período em um ano, parece aceitável que dois anos seja um período razoável, dadas as características e o distanciamento geográfico do empreendimento.

Guardadas as devidas proporções, mas atendendo as A, B, melhores práticas de Governança Corporativa, os peritos expressariam sua opinião sobre as contas da Companhia no período. Infelizmente os critérios de análise não são especificados nos estatutos.

Penalidade para os Administradores e peritos em caso de conivência. 
conclusão

\begin{tabular}{|c|c|c|c|}
\hline \multicolumn{2}{|r|}{$\begin{array}{l}\text { Estatutos da Cia. de Commércio } \\
\text { do Grão Pará e Maranhão }\end{array}$} & \multicolumn{2}{|l|}{ Análise } \\
\hline Art. & $\begin{array}{ll}\text { Texto } \\
\end{array}$ & Texto & Ref. \\
\hline & $\begin{array}{l}\text { os seis [incluem-se aqui os peritos] obrigados a satisfaze- } \\
\text { rem à Companhia a mesma dívida, e perderão logo, por } \\
\text { este mesmo fato, as ações com que tiverem entrado na } \\
\text { Sociedade para o fundo da mesma Companhia. }\end{array}$ & & \\
\hline 24 & $\begin{array}{l}\text { Os dois interessados [peritos] que se nomearem para } \\
\text { tomar contas, serão obrigados a concluí-las dentro do } \\
\text { termo [ao final de] de dois meses, e se neste tempo não } \\
\text { as puderem acabar pedirão aos } 13 \text { Diretores mais tem- } \\
\text { po, os quais lhes não prorrogarão mais do que outros } \\
\text { dois meses. }\end{array}$ & Prazo para divulgação dos exames das contas. & \\
\hline 25 & $\begin{array}{l}\text { Os interessados [peritos] que se nomearem para tomar } \\
\text { as contas dos quatro Administradores não poderão ser } \\
\text { nomeados para as dos anos seguintes, e só passados } \\
\text { seis anos poderão tomar outras contas, e cada um des- } \\
\text { tes dois nomeados vencerá [receberá] cinqüenta mil réis, } \\
\text { por cada conta que tomar. }\end{array}$ & $\begin{array}{l}\text { Duzentos e cinqüenta anos antes de Sarbanes e Oxley } \\
\text { pensarem no assunto, Mendonça Furtado já antevia a } \\
\text { necessidade de rodízio dos analistas das contas/peri- } \\
\text { tos para preservar a lisura da análise das contas do } \\
\text { empreendimento. }\end{array}$ & \\
\hline 26 & $\begin{array}{l}\text { Morrendo qualquer dos } 13 \text { Diretores ou mudando de ter- } \\
\text { ra, da qual não possam cumprir suas obrigações, logo } \\
\text { os acionistas elegerão outro Diretor, e se faltar por qual- } \\
\text { quer das ditas causas algum dos Administradores, logo } \\
\text { os } 13 \text { Diretores farão outro no seu lugar, e se tomarão } \\
\text { contas exatas ao que sair, na forma sobredita. }\end{array}$ & $\begin{array}{l}\text { Sucessão e controles sobre as contas daquele acionis- } \\
\text { ta que se retira da sociedade. }\end{array}$ & \\
\hline 27 & $\begin{array}{l}\text { Os } 4 \text { Administradores, tanto desta cidade [Belém] como } \\
\text { de Lisboa, sempre serão Portugueses, vassalos de S. } \\
\text { Maj., não se admitindo estrangeiro algum, a manos de } \\
\text { não ser casado e naturalizado no Reino. }\end{array}$ & $\begin{array}{l}\text { Manifesta-se aqui a xenofobia característica dos países } \\
\text { latinos. }\end{array}$ & \\
\hline
\end{tabular}

Interessante observar que, em nenhum ponto do estatuto ou ao longo das correspondências encaminhadas por Mendonça Furtado ao irmão, o autor imagina que a administração seria realizada em Lisboa, como de fato viria a ocorrer. O máximo que Mendonça Furtado concede em sua proposta é que haja administradores em ambos os locais: "que os 4 administradores, tanto desta Cidade como de Lisboa, [...]". A ordem de indicação das cidades, em uma época de alta vassalagem e subserviência, sugere que o autor almejava que a administração central do empreendimento se fizesse em Belém, até porque havia sido ele o mentor do projeto. Mas tal não ocorreu. Distante da corte, mesmo contando com o apoio e o alto cargo ocupado pelo irmão, viu seu projeto quase que totalmente reestruturado de acordo com os interesses políticos da época.

O estatuto proposto, ou por estar muito à frente do seu tempo e, por conseqüência, não ser adequadamente entendido, ou talvez porque fosse perfeitamente entendido (mais provável), mas não conviesse aos interesses de uma nação marcada pela corrupção na administração pública, como indicou o próprio Mendonça Furtado na introdução do citado estatuto, foi substancialmente alterado em todos os tópicos que propunham controles.

\section{COMPANHIA DO GRÃO-PARÁ: O ESTATUTO APROVADO}

Em 6 de junho de 1755, o rei de Portugal, D. José I, aprovava os cinqüenta e cinco artigos que compunham a versão final dos Estatutos da Cia. do Grão Pará, denominação oficial do empreendimento. Já no artigo primeiro o conselho de administração, composto por 13 diretores, foi substituído por "um corpo político composto de um provedor, oito deputados ${ }^{10} \mathrm{e}$ um secretário." Com a supressão da diretoria, todo o sistema de escolha dos administradores, bem como as funções inerentes ao cargo foram eliminadas.

De acordo com o artigo terceiro do novo estatuto, os cargos acima seriam preenchidos por meio de eleição entre os sócios que possuíssem participação

\footnotetext{
10 Deputado: cargo de administração por delegação ou incumbência.
} 
acionária superior a 10 mil cruzados e só poderiam votar os sócios que individual ou coletivamente representassem interesses superiores a 5 mil cruzados. Não obstante, para o primeiro mandato de três anos, os cargos foram preenchidos por indicação real, ou seja, à revelia dos sócios.

Por ser de iniciativa privada, o empreendimento poderia ser gerido sem a interferência de qualquer organismo do Estado, exceto o próprio rei, o que lhe concedia liberdade relativa. Cabia aos oito deputados supervisionar a operacionalização do empreendimento.

O exame das contas por dois peritos, com assinatura de opinião sobre as mesmas, foi parcialmente mantido, porém o exame das contas passou a ser efetuado pelo próprio contador da Companhia: "Todos [provedor e deputados] servirão enquanto a Companhia os quiser conservar e lhe tomará contas dos seus recebimentos e dará quitação firmada por dois deputados e seladas com o selo da Companhia depois de serem vistas e examinadas pelo Contador dela." (MENDONÇA, 1982, p. 57).

As atividades da companhia foram substancialmente ampliadas. Segundo os estatutos, a empresa, detendo a exclusividade comercial da capitania do Grão-Pará e Maranhão, poderia comercializar secos e molhados, construir seus navios, capturar navios e respectiva carga às nações consideradas inimigas, bem como efetuar transporte de carga a serviço de terceiros.

O capital da empresa foi definido em um milhão e duzentos mil Cruzados, repartidos em mil e duzentas ações de quatrocentos mil Réis cada uma, pagos metade à vista e o restante em duas parcelas iguais vincendas em quatro e oito meses, respectivamente.

O tempo mínimo para distribuição dos resultados foi mantido em três anos, consoante a minuta do estatuto original, contados a partir da saída da primeira frota. As distribuições posteriores ocorreriam anualmente (Art. 52).

Mantendo uma característica comum à época, o empreendimento possuía duração pré-definida, estipulada em vinte anos, podendo, no entanto, de acordo com o interesse dos acionistas, ser prorrogado por mais dez anos (Art. 53).

A prerrogativa de nomear os oito deputados para o primeiro mandato foi assim descrita no último artigo do estatuto:

\begin{abstract}
Art. 55.
E porque V. majestade ouvindo os suplicantes, foi servido nomear os abaixo declarados para o estabelecimento e governo desta Companhia nos primeiros três anos: Todos eles assinarão este papel em nome do dito Comércio obrigando de per si os cabedaes (capital) com que entram nesta Companhia e em geral os das pessoas que nela entrarem também pelas suas entradas somente [...] Lisboa, 6 de junho de 1755.

\section{Sebastião José de Carvalho e Mello José da Costa Ribeiro Rodrigo de Sande e Vasconcellos Antonio dos Santos Pinto Domingos de Bastos Vianna Estevão José de Almeida Bento José Álvares Manoel F. da Costa João Francisco da Cruz José Francisco da Cruz João de Araújo Lima}

(MENDONÇA, 1982, p. 70)

Majestosa ingratidão! Francisco Xavier de Mendonça Furtado, entusiasta idealizador da Companhia de Comércio e elaborador do estatuto inicial não foi indicado para compor a direção do empreendimento.

Os motivos que levaram o rei a preteri-lo não são claros, mas a opção de colocar seu irmão, o Marquês de Pombal, à frente do projeto é facilmente compreensível: minimizar a resistência daqueles que viam a iniciativa com desdém.

Não se pode esquecer que os donos do poder eram nobres e esses, por uma questão cultural, não trabaIhavam nem estudavam. Essa letargia levou Pombal ao extremo de criar uma instituição de ensino especialmente direcionada a eles: o Colégio dos Nobres.

Nem todos sabem que um dos objetivos de sua criação, talvez o principal, era o de retirar a velha nobreza de Portugal de sua atitude de boçalidade em julgar o trabalho incompatível com esta nobreza, levando os das novas 
gerações a, sem sentir, abandonarem tal atitude, incompatível com a situação de Portugal. O convite ao seu apoio financeiro, como acionistas da nova Companhia de Comércio então formada, saiu vitorioso.

$$
\text { (MENDONÇA, 1982, p. 571) }
$$

Para que se tenha idéia do baixo nível de instrução da época basta informar que, em 1878, portanto mais de um século depois, apenas $14,3 \%$ da população portuguesa sabia ler e escrever (CARVALHO et al., 2002, p. 19).

Para poder contar com a participação dos proprietários do capital sem, contudo, diminuir o status de quem participasse do empreendimento, o estatuto da Companhia, em seu artigo 39, enaltece e incentiva os que a ele aderirem: "E o comércio que nela se fizer na sobredita forma, não só não prejudicará a nobreza das pessoas que o fizerem [...], mas antes pelo contrário será meio para alcançar a nobreza adquirida." (MENDONÇA, 1982, p. 66).

\section{O FIM DA COMPANHIA}

Com a extinção dos privilégios comerciais em 5 de janeiro de 1778, teve início o processo de liquidação da companhia. Em 11 de março foram criadas as Juntas Liquidatórias. Seu objetivo era proceder ao encerramento das contas, à cobrança de dívidas e à venda de mercadorias, navios e outros bens da empresa. Em 11 de outubro de 1821, a Junta de Liquidação da Cia. do Grão-Pará foi anexada à Junta de Liquidação da Companhia de Pernambuco e Paraíba. A burocracia portuguesa somente conseguiria encerrar ambos os empreendimentos, em definitivo, junto ao Banco Comercial de Lisboa, cento e trinta e seis anos depois, em 26 de Dezembro de $1914^{11}$. A documentação relati- va às duas Companhias, bem como a da Junta de Liquidação se encontra na Torre do Tombo, em Lisboa.

\section{CONCLUSÃO}

A procura de mecanismos de proteção dos acionistas sejam eles contra o poder dos acionistas majoritários, seja contra os agentes escolhidos para dirigir os empreendimentos em seu nome, não é uma preocupação nascida ao final do século XX. Enquanto o meio acadêmico procurou caracterizar e atribuir nomes a antigas práticas, como, por exemplo, a Teoria da Agência, os empreendedores, em outras épocas, despreocupados com os rótulos, procuravam estabelecer regras de conduta que resguardassem seus interesses.

Um exemplo claro de tal afirmativa é a minuta original da Companhia Geral de Commércio do Grão Pará e Maranhão, exposta neste artigo. Antecipando em quase duzentos e cinqüenta anos o que hoje denominamos "boas práticas de Governança Corporativa", Mendonça Furtado, Governador daquele Estado, intuitivamente passava para o papel, socorrendo-se apenas de sua memória e experiência, práticas salutares que intentavam alcançar as mesmas finalidades.

Obviamente que nem todas as práticas que hoje compõem os diversos guias elaborados ao redor do mundo foram aplicadas àquela minuta, até porque as necessidades de proteção dos acionistas no século XVIII diferiam substancialmente das atuais, pela própria natureza dos empreendimentos e pelas características comerciais de ambas as épocas. Se forem levados esses aspectos, será possível concluir pela repetição dos processos ou se poderá valer dos dizeres de Mark Twain para quem "Adão foi o único homem que, dizendo coisas interessantes, sabia que ninguém o havia feito antes dele". 
CALPERS - CALIFORNIA PUBLIC EMPLOYEES' RETIREMENT SYSTEM. Disponível em: <www.calpers-governance.org/ principles/international/global/ page09.asp>.

CARLSSON, Rolf. Ownership and value creation: strategic corporate governance in the new economy. $1^{\circ}$ ed. New York: John Wiley \& Sons, 2001.

CARVALHO, José Manuel de Matos. CONDE, Maria de Fátima T. PAIXÃO, Judite Cavaleiro. A First Attempt to Identify Phases and Periods of the Accounting History in Portugal, $9^{\circ}$ World Congress of Accounting Historians, Melbourne, 2002.

EGCI - EUROPEAN SHAREHOLDERS GROUPS "EUROSHAREHOLDERS". Disponível em: <www.ecgi.de/codes/ country_documents/pan_european / european_shareholders.pdf>.

FURTADO, Celso. Formação econômica do Brasil, 17. ed. São Paulo: Ed. Nacional, 1980.

HALLQVIST, Bengt. A História do Instituto Brasileiro de Governança Corporativa, IBGC, 2002.

IANTT - INSTITUTO DOS ARQUIVOS NACIONAIS TORRE DO TOMBO. Disponível em: <www.iantt.pt>.
IBGC - INSTITUTO BRASILEIRO DE GOVERNANÇA CORPORATIVA. Disponível em: <www.IBGC.org.br>.

MACHADO, José A. B. A História da Bolsa. Disponível em <www.geocities.com/WallStreet/Exchange/1842/histbolsa.htm>, consultado em 10.02.2004.

MENDONÇA, Marcos Carneiro de. Aula de Comércio, Rio de Janeiro: Xerox do Brasil, 1982.

PESTANA, Flávio Bonfim (coord). Dicionário Prático da Língua Portuguesa. $3^{\underline{a}}$ ed. São Paulo: Empresa Folha da Manhã S.A. 1994.

SIFFERT FILHO, Nelson. Governança Corporativa: padrões internacionais e evidências empíricas no Brasil. Revista do BNDES, Rio de Janeiro: $n^{\circ} .10$, p. 1-23, 1998

SILVEIRA, Alexandre de Miceli, Governança Corporativa, desempenho e valor da empresa no Brasil, São Paulo: 2002. Dissertação. Faculdade de Economia, Administração e Contabilidade da Universidade de São Paulo.

YIN, Robert K. Case Study Research, Design and Methods. $2^{\circ}$ ed, 1994

NOTA:

Endereço dos autores:

ÁLVARO RICARDINO

Centro Universitário Santo André

Av. Princípe de Gales, 821 - Príncipe de Gales

Santo André - SP

09060-650

SOFIE TORTELBOOM AVERSARI MARTINS

Fipecafi

Rua Alvarenga, 2147 - Butantã

São Paulo - SP

05509-005 